\title{
JSAEE \\ THE INFLUENCE OF ORGANIZATION CULTURE AND INTERPERSONAL COMMUNICATION ON THE WORK ATTITUDE OF PRIVATE JUNIOR HIGH SCHOOL TEACHERS IN TANJUNG PRIOK DISTRICT, JAKARTA
}

\author{
Elfridauli \\ Universitas Negeri Jakarta \\ elfrida@tbcs.sch.id
}

\begin{abstract}
Work attitude of teachers greatly influences the success of an education, which is influenced by several factors such as organizational culture, job satisfaction, job involvement, compensation, work comfort and interpersonal communication. The purpose of this study is to determine the influence of organizational culture and interpersonal communication on the work attitude of private junior high school teachers in Tanjung Priok District. This research was conducted using survey method with quantitative approach and path analysis technique. The populations in this study were 307 teachers with 75 research samples of teachers selected using simple random sampling technique. Data were obtained through questionnaire and analyzed using path analysis technique. Based on the results of data analysis in this study, it can be concluded: (1) organizational culture has a direct positive influence on teacher work attitude; (2) interpersonal communication also has a positive direct effect on teacher work attitude; (3) organizational culture has a positive direct effect on interpersonal communication. Therefore, work attitude can be developed through the improvement of organizational culture and interpersonal communication.
\end{abstract}

Keywords: Private Junior High School Teachers, Organizational Culture, Interpersonal Communication, Work Attitude.

Education is the main thing to turn an unable person become capable person, then education is also a guide to one's character. Education is also one of the determinants of the nation's character development, as set forth in the educational objectives of Law no. 20 Year 2003 on National Education System, Article 3 which reads: "The purpose of national education is to develop the potential of learners to become human beings who believe and fear God Almighty, have noble character, healthy, insightful, capable, creative, independent, and become a democratic and responsible citizen ".

One related to educational institutions is the educator or the so-called teacher is one of the spearhead of achieving the expected educational goals and also an example of life both in the classroom and outside the classroom for learners.

In improving the positive work attitude of teachers in the organization the need for support from organizational culture as there are always trainings, seminars and discussions on teaching methods in subject MGMP. According Darmawan (Darmawan, 2013) organizations can take place and arrived at the vision, mission, and objectives through the management process. To lead an organization, a manager has the main tasks of being interpersonal, informational and decision makers.

Each organization has an organizational culture that can characterize the 
character of the organization. A strong organizational culture will create a form of employee behavior and work attitude of the teacher, then it will affect the competition between organizations. For example in a school organization, how strong a school's organizational culture will also affect the teacher's attitude to the school. With the attitudes and attitudes that teachers show will be the hallmark of a school will be the increasing quality of education. Then the organization has an interpersonal communication that goes well so that the communication will be able to influence the work attitude of the teacher.

According to Sudaryono (Sudaryono, 2013), cultural differences have a major impact on organizational performance and the quality of work experience experienced by members of the organization. Thus the organizational culture is an invisible force but can affect the thoughts, feelings and actions of those who work within an organization. Just as the person of every human being has different characteristics, characters and values in the background of the family background, comes from different tribes and has different habits in every family and environment that make up each person's personality.

According to Sugiarta et al (Sugiarta, 2013) organizational culture have a positive effect on teacher performance, follow the teacher competency development program, participate in developing organizational culture in obeying school rules and programs. Organizational culture will provide a value to every teacher at work, the culture will also give the teacher attitude on the work being done and completed. Whether the teacher is satisfied with his job and can make a stay in his work is also influenced by the culture of an organization.

According to Ivancevich et al (Ivancevich, 2006) organizational culture involves shared expectations, values and attitudes, and all may affect the individual, group and organizational processes. Distinguishing strong cultures from weak cultures is often very useful because strong cultures are characterized by the presence of employees with shared core values. The more employees who share and receive core values, the stronger the culture, and the greater the impact on behavioral behavior.

In addition to organizational culture there is also communication in the move. Culture can help an employee work in accordance with organizational culture and agreed rules. Although organizational culture can also help but without any communication, the values of the organization cannot be conveyed maximally. According to Nurrohim and Anatan [5] the success of the organization is strongly influenced by the capability and competence of each individual and cooperation among team members in the organization. In establishing cooperation to achieve these goals required communication.

According to Tahjudin Nor (Nor, 2013) the company leadership must really pay attention to the satisfaction of organizational communication in the organization, because with intensive attention to work motivation in the organization then it is expected that employees will work harder to realize organizational goals. According to Wiyani (Wiyani, 2015) building a relationship through communication can be done in meet face to face to exchange information or not need to meet directly but by using electronic tools. Communication is an organizational driver, because the goals of the organization will be difficult to achieve without communication. 
Communication in the process of organization becomes very less due to the increasing variety of every person in the organization. Then the added increase in technology makes employees reduce communication directly and many are busy personal interests. While the process of organization required communication to create teacher work attitude.

Organizational culture and interpersonal communication have a positive effect on performance. Organizational culture can also increase the competence of teachers, thus positive attitudes toward the profession or on the job can also increase. According Sawaludin (Sawaludin, 2013) interpersonal communication also affects the social dimension within the organization, making effective communication and teachers increasingly work hard to take responsibility for the work.

According to Norlena (Norlena, 2015) school as a formal organization, has a structure that allows schools to function as a good educational institution. In it there are a group of people who work together to achieve a goal that is the generation of the nation's intellect and the infrastructure facilities. According to Wuryantina [10] the school is also a form of moral organization, in contrast to other profit-oriented organizational forms. It brings logical consequences for each component of the school to synergize, have the same commitment and apply the school's norms and values to achieve the goals of school education.

Working together is also inseparable from organizational culture, interpersonal communication and work attitude. Many teachers are not following the rules of the school's organizational culture, many are self-centered and do not build active and positive communication. It then affects the teacher's declining work attitude, many of which provide a lazy working attitude, inconsistent work attitude in guidance, unemployed work attitude and many teaching teachers only for an economic reason. If the teacher teaches without any sense of sincerity then all of that becomes bland, because the teacher's work is not an object but to man to man.

According to Librawati et al (Librawati, 2013) work attitude of teachers will be able to influence the success of a school. How the attitude of teachers in serving students and how the attitude of teachers in interacting to peers and to the leadership. The work attitude of a teacher is very important because through attitude will affect the personal attitude, group attitude like organization and will affect organizational goals.

According to research I Wayan Karya et al (Karya, 2013) work attitude of teachers in responding to complete tasks and responsibilities and the work environment will be able to affect the performance of teachers and impact on the results of student grades in schools. Teachers' attitudes include three attitudes: job satisfaction, organizational commitment and job involvement. According to Khoiri's research (Khoiri, 2017) the quality of working life has a direct positive effect on work attitude, meaning that improving the quality of working life leads to an increase in teacher work attitude

According to Sugiarta (Sugiarta,2012) the teacher's attitude to the job should always be positively strived by the teacher, beside that the teacher should always increase the knowledge and skill, thereby the ability of the teacher will increase and the quality education will be realized. Factors attitude of teachers is influenced both from outside and from within, meaning how the attitude of teachers to the 
work that is influenced from the factor in the teacher. While external factors can also be influenced by organizational culture and the quality of communication between teachers is then aided by the ability of the teacher both experience and ability

Tanjung Priok Sub-district is one of the sub-districts in North Jakarta Municipality, DKI Jakarta. Tanjung Priok sub district has an area of $25.13 \mathrm{~km} 2$. According to data from the Education Office of North Jakarta Municipality, Tanjung Priuk Sub-district has 46 Junior High Schools, consisting of 35 private schools and 11 public schools, with a total of 635 teachers and about 12,506 children. Especially for private junior high school the number of teachers there are 307 people and the number of students as many as 6014 children.

This study aims to determine whether there is direct influence of organizational culture on teacher work attitude, direct influence of interpersonal communication on teacher work attitude, direct influence of organizational culture toward interpersonal communication. The results of this study are expected to be a reference to teachers in private junior high schools in Tanjung Priok subdistrict to be able to evaluate and improve teacher work attitude.

\section{METHODS}

This research was conducted at Private Junior High School of Tanjung Priok Sub-distric, North Jakarta from April to May 2018. The research method used is survey method by collecting data by distributing questionnaires to teachers whose results are then processed through to determine the effect between variables that exist. This study using quantitative approach through causality, the method is used to explain the influence of independent variables on the dependent variable in this study.

Figure 1 shows the influence model between the exogenous (free) variable and the endogenous variable (bound) so that it can be understood easily and clearly. This study uses a double paradigm with two independent variables and one dependent.

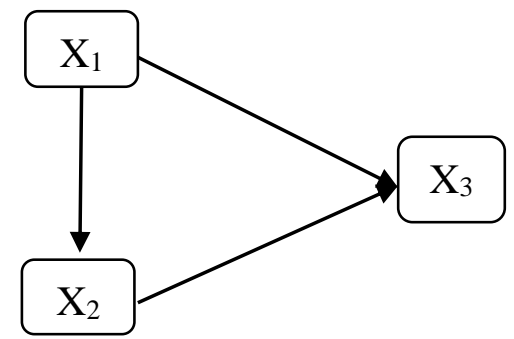

Figure 1. Double paradigm with two independent variables $X_{1}$ and $X_{2}$, and one dependent variable $\mathrm{X}_{3}\left(\mathrm{X}_{1}\right.$ : Organizational Culture, $\mathrm{X}_{2}$ : Interpersonal Communication, $\mathrm{X}_{3}$ : Teacher Work Attitude)

Based on Figure 1, teacher work attitude $\left(\mathrm{X}_{3}\right)$ is dependent variable. Organizational culture $\left(\mathrm{X}_{1}\right)$ and interpersonal communication $\left(\mathrm{X}_{2}\right)$ are independent variables. The constellation of these influences illustrates that organizational culture and interpersonal communication are independent variables that have an 
influence on teachers' work attitude.

The population in this study comes from private junior high school teachers in Tanjung Priok sub-district, amounting to 307 teachers. The number of research subjects sampled in this study are as many as 75 people. This amount is obtained from the formula of determining the number of Slovin formula samples, as stated by Juliansyah Noor (Noor, 2011) with a $10 \%$ precision or $90 \%$ confidence level. The formula is as follows:

$$
\begin{gathered}
\mathrm{n}=\frac{N}{1+\left(N e^{2}\right)} \\
\mathrm{n}=\mathrm{N} /(1+(\square \mathrm{Ne} \square \wedge 2))
\end{gathered}
$$

information :

$\mathrm{n}=$ number of samples

$\mathrm{N}=$ total population

$\mathrm{E}=$ error tolerance (level of significance)

If we examine as many as 307 teachers, then the sample size according to Slovin formula will be:

$$
\begin{gathered}
\mathrm{n}=\frac{N}{1+\left(N e^{2}\right)} \\
\mathrm{n}=\frac{307}{1+\left(307(0,1)^{2}\right)} \\
\mathrm{n}=75,429 \approx 75
\end{gathered}
$$

Sampling is done by simple random sampling where each member of the population is given equal opportunity to be a research sample.

In collecting research data used questionnaire given to the respondents are teachers of Private Junior High School Tanjung Priok District. Each questionnaire was developed in the lattice of each research variable. For the purposes of this study, three instruments have been formulated, namely instruments used to measure organizational culture variables, interpersonal communication and teacher work attitude, as shown in Table 1, Table 2, and Table 3.

The concepts underlying the preparation of the instruments depart from the indicators of the research variables. Then the lattice is spelled out into several statements. Alternative answers for each statement are as follows: (a) very often, (b) often, (c) rarely, (d) never, (e) never.

Category positive statements are given: very often $=5$, often $=4$, rarely $=3$, never $=2$, and never $=1$, whereas negative statements are given the opposite value ie: very often $=1$, often $=2$, rarely $=3$, never $=4$, and never $=5$. 
Table 1. Work attitude grille

\begin{tabular}{|c|c|c|c|}
\hline No & Indicator & Number Item & $\underset{t}{\text { Amoun }}$ \\
\hline 1 & $\begin{array}{l}\text { Job assessment / } \\
\text { response }\end{array}$ & $\begin{array}{l}1,2,3,4,5,6, \\
7,8\end{array}$ & 8 \\
\hline 2 & Job involvement & $\begin{array}{l}9,10,11,12, \\
13,14\end{array}$ & 6 \\
\hline 3 & $\begin{array}{l}\text { Response to the } \\
\text { profession }\end{array}$ & $\begin{array}{l}15,16,17,1819,2 \\
0,21,22\end{array}$ & 8 \\
\hline 4 & Confidence & $23,24,25,2627$ & 5 \\
\hline 5 & $\begin{array}{l}\text { Improve knowledge } \\
\text { / expertise }\end{array}$ & $28,29,30,3132$ & 5 \\
\hline 6 & Punctuality & $33,34,35,36,37$ & 5 \\
\hline 7 & Service quality & $\begin{array}{l}38,39,40,41,42,4 \\
3,44,45\end{array}$ & 8 \\
\hline
\end{tabular}

Table 2. Organization Culture Grille

\begin{tabular}{|c|l|l|c|}
\hline No & \multicolumn{1}{|c|}{ Indicator } & \multicolumn{1}{|c|}{ Number Item } & $\begin{array}{c}\text { Amoun } \\
\mathrm{t}\end{array}$ \\
\hline 1 & School rules & $1,2,3,4,5,6$ & 6 \\
\hline 2 & $\begin{array}{l}\text { Appreciation of } \\
\text { teachers }\end{array}$ & $\begin{array}{l}7,8,9,10,11, \\
12,13,14\end{array}$ & 8 \\
\hline 3 & Training program & $\begin{array}{l}15,16,17,18, \\
19,20,21,22\end{array}$ & 8 \\
\hline 4 & Mutual cooperation & $23,24,25,26,27$ & 5 \\
\hline 5 & Work procedures & $28,29,30,31,32$ & 5 \\
\hline 6 & Solidarity & $33,34,35,36,37$ & 5 \\
\hline 7 & Organizational & $\begin{array}{l}38,39,40,41, \\
42,43,44,45\end{array}$ & 8 \\
\hline
\end{tabular}

Table 3. Interpersonal Communication Grille

\begin{tabular}{|c|l|l|c|}
\hline No & \multicolumn{1}{|c|}{ Indicator } & \multicolumn{1}{|c|}{ Number Item } & $\begin{array}{c}\text { Amoun } \\
\mathrm{t}\end{array}$ \\
\hline 1 & Know each other & $1,2,3,4,5,6,7$ & 6 \\
\hline 2 & Cooperate & $8,9,10,11,12$ & 8 \\
\hline 3 & Perception & $\begin{array}{l}13,14,15,16,17, \\
18\end{array}$ & 8 \\
\hline 4 & Sympathy & $19,20,21,22,23$ & 5 \\
\hline 5 & Communicative & $24,25,26,27,28,2$ & 5 \\
\hline
\end{tabular}




\begin{tabular}{|c|l|l|c|}
\hline & & $9,30,31$ & \\
\hline 6 & Openness & $\begin{array}{l}32,33,34,35, \\
36,3,38,39\end{array}$ & 5 \\
\hline 7 & Support & $\begin{array}{l}40,41,42,43, \\
44,45\end{array}$ & 8 \\
\hline
\end{tabular}

\subsection{Instrument Validity Testing}

Test the validity of research instrument aims to see the description of the validity of each instrument research instrument. The grain validity test is required to confirm that the items of the research instrument used in the data retrieval are valid. Empirically, this is done by looking at the correlation coefficient (pearson product moment) between the questions with the answer score.

Instrument validity is tested by product moment formula as follows:

$$
r_{x y}=\frac{n\left(\sum X Y\right)-\left(\sum X\right)\left(\sum Y\right)}{\sqrt{\left[n\left(\sum X^{2}\right)-\left(\sum X\right)^{2} \mid n\left(\sum Y^{2}\right)-\left(\sum Y\right)^{2}\right]}}
$$

Information :

$r_{12}$ : Product moment correlation coefficient

$\Sigma X$ : Number of scores in distribution $\mathrm{X}$

$\Sigma Y$ : Total score in distribution $\mathrm{Y}$

$\Sigma X Y$ : Number of scores $X$ and $Y$

$\Sigma X^{2}$ :The number of results squared in the distribution $X$

$\Sigma \mathrm{Y}^{2}$ :The number of results squared in distribution $\mathrm{Y}$

$\mathrm{n}$ : Number of samples (respondents)

Criteria validity of one instrument research instrument is if the value of $r_{\text {count }} \geq r_{\text {tabel }}$. The amount of $r_{\text {tabel }}$ is determined by the level of significance and degree of freedom (dk). The level of significance is set at $\alpha=0.05$. While the degree of freedom is the number of samples minus $1(n-1)$.

\subsection{Calculation of Instrument Reliability}

Calculation of reliability is the calculation of the consistency of questionnaire data using Cronbach Alpha formula. The use of this formula is tailored to the scoring technique performed at the time of the item in the instrument. Calculation reliability of interpersonal communication instruments as much as 45 points statement.

\subsection{Data analysis technique}

Data analysis used in this research is descriptive and inferential analysis. Descriptive analysis presents the data characteristics of each variable in the form of 
data presentation, central size, and size of data dissemination. The data presentation is displayed in the mean, median, and mode. As for the size of the distribution is presented in the form of variance and standard deviation.

Inferential analysis uses path analysis. But before using the path analysis, firstly tested the requirements analysis, namely normality test, significance test, and linearity. While to calculate path coefficient by using correlation coefficient from each causal relation.

Variables in causal research are divided into two, namely endogenous and exogenous variables. Endogenous variable is a variable influenced by exogenous variable, which in this study variable work attitude of teacher $\left(\mathrm{X}_{3}\right)$. While exogenous variable in this research is organizational culture variable $\left(\mathrm{X}_{1}\right)$. Besides acting as an endogenous variable, the interpersonal communication variable $\left(\mathrm{X}_{2}\right)$ is also an exogenous variable

The statistical hypothesis used in this research is as follows:

1. The first hypothesis there is a direct positive influence of organizational culture $\left(\mathrm{X}_{1}\right)$ on Work Attitude $\left(\mathrm{X}_{3}\right)$.

2. The first hypothesis there is a direct positive influence of Interpersonal Communication $\left(\mathrm{X}_{2}\right)$ on Work Attitude $\left(\mathrm{X}_{3}\right)$.

3. The first hypothesis there is a direct positive influence Organizational Culture $\left(\mathrm{X}_{1}\right)$ to Interpersonal Communication $\left(\mathrm{X}_{2}\right)$.

\section{RESULT AND DISCUSSION}

\subsection{Testing Requirements Analysis}

Parametric statistical analysis is used with the assumption that the data of each research variable being analyzed is normally distributed. In this section carried out the process of testing the requirements of analysis as a condition for the regression technique which is a group of parametric statistics can be applied for the purpose of hypothesis testing.

Path analysis (path analysis) can be done if the estimation between exogenous variables to endogenous variables is linear. Thus if the above conditions are met then the regression analysis and path analysis can be done. The requirement of path analysis is the sample of research coming from normally distributed populations and the influencebetween the variables in the model must be significant and linear. Therefore, testing of the two conditions applicable in the path analysis needs to be done before the model testing process, which includes:

- Normality test

- Test of Significance and Linearity of Regression Coefficients

\subsection{Normality test}


From the results of the normality test results obtained results as follows:

\subsubsection{Test Normality Error Estimated $X_{3}$ Regression over $X_{1}$}

The result of data analysis shows that calculation $\mathrm{L}_{\text {count }}=0,051$ smaller than $\mathrm{L}_{\text {table }}$ ( $n=75 ; \alpha=0,05)$ equal to 0,102 . Since the $\mathrm{L}_{\text {count }}$ value is less than $\mathrm{L}_{\text {table }}$ then the distribution of work attitude data over organizational culture tends to form a normal curve.

\subsubsection{Test Normality Error Estimated $X_{3}$ Regression over $X_{2}$}

The result of data analysis shows that calculation Lcitung $=0,063$ is smaller than Ltabel $(n=75 ; \alpha=0,05)$ equal to 0,102 . Since the Lhitung value is less than Ltabel then the spread of work attitude data on interpersonal communication tends to form a normal curve.

\subsubsection{Test Normality Error Estimated Regression $X_{2}$ over $X_{1}$}

The result of data analysis shows that calculation Lcitung $=0,061$ less than Ltabel $(n=75 ; \alpha=0,05)$ equal to 0,102 . Since the Lhitung value is less than Ltabel then the distribution of interpersonal communication data over organizational culture tends to form a normal curve.

Taking into account the prices of Lhitung and Ltabel on the normality test, it can be concluded that all good data of work attitude over organizational culture, work attitude on interpersonal communication, and interpersonal communication over organizational culture come from normal distributed samples.

\subsection{Test of Significance and Linearity of Regression}

Hypothetical test of the research is done by considering the result of regression analysis and correlation analysis. To predict the model of one variable relationship with other variables used regression analysis. Meanwhile, to know the influence between research variables used correlation analysis. The overall test results of significance and linearity of regression are summarized in Table 4.

Table 4. Significance Test Results and Regression Linearity Test

\begin{tabular}{|c|c|c|c|c|c|c|}
\hline \multirow[b]{2}{*}{$\operatorname{Reg}$} & \multirow[b]{2}{*}{ Equation } & \multicolumn{2}{|c|}{ Regression Test } & \multicolumn{2}{|c|}{ Linearity Test } & \multirow[b]{2}{*}{ Conclusion } \\
\hline & & $F_{\text {count }}$ & $\begin{array}{c}F_{\text {table }} \\
\alpha=0,0 \\
1\end{array}$ & $F_{\text {count }}$ & $\begin{array}{c}F_{\text {table }} \\
\alpha=0,0 \\
5\end{array}$ & \\
\hline $\begin{array}{l}X_{3} \\
\text { on } \\
X_{1}\end{array}$ & $\hat{X}_{3}=33,91+0,56 X_{1}$ & $\begin{array}{l}45,94 * \\
*\end{array}$ & 7,00 & $\underset{s}{0,90^{n}}$ & 75 & $\begin{array}{l}\text { Very } \\
\text { significant } \\
\text { regression / } \\
\text { Linear } \\
\text { regression }\end{array}$ \\
\hline $\begin{array}{l}X_{3} \\
\text { on } \\
X_{2}\end{array}$ & $\hat{X}_{3}=31,60+0,58 X_{2}$ & $\begin{array}{c}33,63 * \\
*\end{array}$ & 6,99 & $\underset{\mathrm{s}}{1,21^{\mathrm{n}}}$ & 75 & $\begin{array}{l}\text { Very } \\
\text { significant } \\
\text { regression / } \\
\text { Linear } \\
\text { regression }\end{array}$ \\
\hline
\end{tabular}




\begin{tabular}{|c|c|c|c|c|c|c|}
\hline $\begin{array}{l}\mathrm{X}_{2} \\
\text { on } \\
\mathrm{X}_{1}\end{array}$ & $\begin{array}{c}\hat{\mathrm{X}}_{2}=108,81 \\
+0,356 \mathrm{X}_{1}\end{array}$ & $\begin{array}{c}14,67 * \\
*\end{array}$ & 6,99 & $\frac{1,03^{\mathrm{n}}}{\mathrm{s}}$ & 75 & $\begin{array}{l}\text { Very } \\
\text { significant } \\
\text { regression / } \\
\text { Linear } \\
\text { regression }\end{array}$ \\
\hline
\end{tabular}

Information :

**: Very significant

Ns : Non significant (Linear regression)

\subsection{Hypothesis testing}

Based on the results of previous analysis then performed hypothesis testing by using path analysis (path analysis). The direct path effect analysis of each variable is shown in Table 5.

Table 5. The results of the path analysis of the direct influence of each variable

\begin{tabular}{|l|c|c|c|c|}
\hline \multirow{2}{*}{$\begin{array}{l}\text { Direct } \\
\text { Influence }\end{array}$} & \multirow{2}{*}{$\begin{array}{c}\text { Path } \\
\text { coefficient }\end{array}$} & \multirow{2}{*}{$t_{\text {count }}$} & $\begin{array}{c}\alpha= \\
0,05\end{array}$ & $\begin{array}{c}\alpha= \\
0,01\end{array}$ \\
\hline $\begin{array}{l}\mathrm{X}_{1} \text { against } \\
\mathrm{X}_{3}\end{array}$ & 0,470 & $5,150^{* *}$ & 1,99 & 2,65 \\
\hline $\begin{array}{l}\mathrm{X}_{2} \text { against } \\
\mathrm{X}_{3}\end{array}$ & 0,369 & $4,041^{* *}$ & 1,99 & 2,65 \\
\hline $\mathrm{X}_{1}$ againt $\mathrm{X}_{3}$ & 0,409 & $3,865 * *$ & 1,99 & 2,65 \\
\hline
\end{tabular}

Based on the result of path analysis, the coefficient value of the direct influence of organizational culture (X1) on teacher work attitude (X3) is equal to 0,470 with value of tcount equal to 5,150. The ttable value for $\alpha=0.01$ is 2.65 . Because the value of t count is greater than ttable then $\mathrm{H}_{0}$ is rejected and $\mathrm{H}_{1}$ is accepted. It shows that organizational culture has a direct effect on work attitude acceptable. The results of the first hypothesis analysis provide findings that the organizational culture directly affect the work attitude. It can be concluded that work attitude is directly influenced by organizational culture. The better the organizational culture leads to better working attitudes.

From the calculation of path analysis shows there is direct influence of interpersonal communication to work attitude. The coefficient value of the line is equal to 0.369 and the tcount is equal to 4.041 . The ttable value for $\alpha=0.01$ is 2.65. Because the value of $t$ count is greater than ttable then $\mathrm{H}_{0}$ is rejected and $\mathrm{H}_{1}$ is accepted. It shows that interpersonal communication has a direct effect on work attitude acceptable. The results of the second hypothesis analysis provide findings that interpersonal communication directly affect the work attitude. Thus it can be concluded that work attitude is directly influenced by interpersonal communication. The better interpersonal communication leads to a better working attitude.

From the calculation of path analysis shows there is direct influence of 
organizational culture to interpersonal communication. The path coefficient value is equal to 0.409 and the tcount is equal to 3,865 . The ttable value for $\alpha=0.01$ is 2.65. Because the value of $t$ count is greater than ttable then $\mathrm{H}_{0}$ is rejected and $\mathrm{H}_{1}$ is accepted. It shows that organizational culture directly influences interpersonal communication is acceptable.

The results of the third hypothesis analysis provide findings that the organizational culture directly affect the interpersonal communication. Thus it can be concluded that interpersonal communication is directly influenced by organizational culture. The better the organizational culture leads to better interpersonal communication.

\section{CONCLUSIONS}

Based on the results of research conducted on private junior high school teachers in Tanjung Priok subdistrict, the conclusion of the study is that organizational culture has a direct effect on work attitude, which means improving the quality of organizational culture leads to improvement of work attitude of private junior high school teachers in Tanjung Priok sub district. Interpersonal communication has a direct effect on work attitude, meaning that the increase of interpersonal communication causes the improvement of work attitude of private junior high school teachers in Tanjung Priok sub district. Organizational culture directly influences interpersonal communication, which means the improvement of organizational culture leads to an increase in interpersonal communication of private junior high school teachers in Tanjung Priok sub-district.

\section{REFERENCES}

Darmawan. D, Principles of Organizational Behavior, Pena Semesta, Surabaya, 2013.

Ivancevich, J.M. Organizational Behavior and Management. Erland, Jakarta, 2006. Karya, I.W, IGA. Suhandana, M .Yudayana, "Contribution of Teacher Competence, Teacher Profession Attitude, and Work Motivation on Teacher Performance of SMA Negeri 1 Sukawati." e-Journal of Graduate Program of Ganesha University of Education, 4, pp. 1-11. 2013.

Khoiri, M. "The Influence of Quality Work Life And Work Attitude of Job Satisfaction of Teachers of Senior High School State of Jekan Raya, Palangka Raya, Central Kalimantan Province." EDUKA Journal of Education, Law and Business, 1 (5), pp. 96-112. 2017.

Librawati, Y., IGK Sunu. "Influence Analysis of Professional Attitudes, School Work Climate and Principal Leadership Style on Teacher Performance at SMP Negeri Sukawati District." e-Journal of Graduate Program of Ganesha University of Education, 4, pp. 13-24, 2013

Nor, F.T. "Relationship of Organizational Communication Satisfaction with Employee Motivation at PT. Srikandi Plastic Sidoarjo.” E-Communication Journal, 1(1), pp. 1-10, 2013

Nurrohim, H and Anatan, L. "Effectiveness of Communication in Organizations. Journal of Management, 7(4), pp. 1-9. 2015 
Norlena, I. "School as a Formal Organization (Structural Relationships)". Tarbiyah Islamiyah, 5 (2), pp. 43-55. 2015

Noor, J. Research Methodology, Prenada Media Group, Jakarta, 2011.

Sawaludin, Proper Organization Culture and Interpersonal Communication Skills Improve Teacher Performance. Journal of Economic and Social Sciences, 3 (1), pp. 73-84, 2013

Sudaryono, Culture \& Organizational Behavior, LCI, Jakarta, 2013.

Sugiarta. "The influence of teacher attitudes on work and experience of education and training on professional competence of SMPN sports teacher in District Jepara.” Journal of Management Education, 1(3), pp. 1-10, 2012.

Sugiarta, M.P, N. Dantes, and N. Natajaya, "Determination of Teachers' Attitudes to Her Professional, Self Concept, and School Working Climate on Primary School Teacher Performance in Level IV Sukasada," Journal of Primary Education, 3, pp. 1-9, 2013.

Wiyani, N.A., Teaching Professional Ethics. Gava Media. Yogyakarta. 2015.

Wuryantina, I "School Organization Culture and Achievement Motivation with Teacher Performance at State Elementary School Adiarsa West Karawang Cluster. Journal of Primary Education, 6 (2), pp 242-253. 2015 